\title{
Klapálek's Kamimuria (Plecoptera: Perlidae) types in the National Museum Prague
}

\author{
D. MuRÁNYI ${ }^{1} \&$ W.H. LI $^{2}$
}

\begin{abstract}
${ }^{1}$ Dávid Murányi, Department of Civil and Environmental Engineering, Ehime University, Bunkyo-cho 3, Matsuyama, 790-8577 Japan, and Department of Zoology, Hungarian Natural History Museum, H-1088 Budapest, Baross u. 13, Hungary. E-mail: muranyi@cee.ehime-u.ac.jp, muranyi@nhmus.hu

${ }^{2}$ Weihai Li, Department of Plant Protection, Henan Institute of Science and Technology, Xinxiang, Henan, 453003 China. E-mail: lwh7969@163.com
\end{abstract}

\begin{abstract}
Three species of the genus Kamimuria Klapálek, 1907 are redescribed or a complementary description is provided on the basis of specimens kept in the National Museum Prague (NMP): male, female and egg of $K$. fulvescens Klapálek, 1912 is redescribed from syntypes, the male of K. lepida Klapálek, 1913 is redescribed on the basis of original specimen. Also, a complementary description based on the holotype of $K$. similis is provided. Furthermore, comments are provided on the basis of type or original specimens of the nine additional Kamimuria taxa that can be found in the NMP. Distribution area of the genus is discussed and depicted on a map.
\end{abstract}

Keywords. Stoneflies, $K$. fulvescens, $K$. lepida, K. similis, redescription, China, Taiwan, Vietnam

\section{INTRODUCTION}

$\mathrm{G}$ enus Kamimuria Klapálek, 1907b was erected for two new and an already described Japanese species, as a subgenus of Perla Geoffroy, 1762. Soon, Klapálek elevated it to generic rank (Klapálek 1912a), and later established type species as Perla tibialis Pictet, 1841 from Japan (Klapálek 1923). Altogether, he described 15 species in this genus (Klapálek 1907b, 1912a, 1912b, 1913, 1916, 1921, 1923), but the generic definition remained poorly established. Six of his Kamimuria were transferred to different genera (Agnetina Klapálek, 1907a, Paragnetina Klapálek, 1907b, Tyloperla Sivec \& Stark, 1988 (in: Sivec et al., 1988), Xanthoneuria Uchida, 2011 (in: Uchida et al. 2011)), while an additional four species were transferred to Kamimuria from the genera Marthamea Klapálek, 1907a and Paragnetina. Illies (1966) even synonymized Kamimuria with Perla. Finally, Zwick (1977) redefined it as a valid genus, and subsequently it is treated as the Asian sister group of Perla.

After his death in 1919, the collection of František (Franz) Klapálek came to Jaromír Šámal, who edited and published many of his half-done manuscript years later (e.g. Klapálek 1923). However, Šámal was executed in 1942, and finally the collection was acquired by the National Museum Prague (NMP) after the World War II, in chaotic order, but survived still in good condition. Since then, many stonefly researchers have studied it and traced most of the types (Bojková \& Soldán 2013, Raušer 1968, Sivec et al. 1988, Zwick 1982), but still, we are in need of a careful overview as was done on the Plecoptera types of Burmeister, Pictets and Enderlein (Zwick 1971, 1973).

During July 2014, the first author searched and databased all the types that were recognizable, in the frame of a SYNTHESYS project. In this paper the Kamimuria types available in the NMP are enumerated. Some of Klapálek's original but nontype Kamimuria specimens, especially those that were included in Klapálek's revisionary works ('plesiotypes'), are also enumerated. NMP types of the species originally described as Kamimuria but later transferred to other genera (Agnetina circumscripta (Klapálek, 1912a), A. praetusta (Klapálek, 1912a), Kamimuria schenklingi Kla- 
pálek, 1912 (junior synonym of Tyloperla formosana (Okamoto, 1912)) and Xanthoneuria bolivari (Klapálek, 1907)) are excluded from the present work.

Many type specimens of Klapálek's taxa that were described on the basis of materials borrowed from foreign collections, especially those from Museum National d'Histoire Naturelle, Paris (MNHN) and Zoological Institute, Russian Academy of Sciences, St. Petersburg (RAS) were left in his personal collection after his early death. Later, these were transferred to NMP together with his own properties and treated together as the 'Klapálek Collection' even though these specimens were stated in the original descriptions to be deposited in their original collections. Many of the specimens are even labelled with the museum's name but after a hundred years it is obviously more convenient to keep these specimens together with the bulk of his materials, especially because the Klapálek Collection has just received proper new storage facilities and a well searchable database.

\section{MATERIAL AND METHODS}

The specimens examined are stored dry in the Department of Entomology, Natural History Museum, National Museum Prague (NMP).

Specimen terminalia was cleared in $\mathrm{KOH}$ and the aedeagus for each was everted with the cold maceration technique (Zwick 1983). Terminalia and aedeagus for each specimen are stored in a microvial with glycerine pinned beneath the specimen. Drawings were made with the aid of a drawing tube applied to a Nikon SMZ800 microscope. SEM images were made using goldpalladium coating and a Hitachi S-2600N scanning electron microscope. Further illustrations were made with Nikon D70s and Leica C cameras. Terminology mainly follows Sivec \& Stark (2008).

Distributional data were compiled from literature information from various sources refe- renced in Plecoptera Species File (PSF) (DeWalt et al. 2015). Whereabouts of type localities were traced in various travel reports by, or about the collectors (Basset 2009; Kozlov 1947).

\section{TAXONOMY}

\section{Kamimuria amoena Klapálek, 1912a}

\author{
(Appendix figures 1-2)
}

Kamimuria amoena Klapálek, 1912: Klapálek, 1912a: 87. (original description of male and female); Klapálek 1923: 21. (complementary description of male and female); $\mathrm{Wu}$ 1935: 302. (catalogue); Wu 1938: 49. (monography); Claassen 1940: 121. (catalogue); Zwick 1977: 116. (comb. rev. by removing Kamimuria Klapálek, 1907b from synonymy of Perla Geoffroy, 1762); Sivec et al. 1988: 32. (checklist); Zhiltzova 1995: 12. (type catalogue of RAS specimens); Du et al. 1999: 60. (checklist); Sivec \& Stark 2008: 137. (checklist); Stark \& Sivec 2013: 117. (checklist); DeWalt et al. 2015 (catalogue).

Perla amoena (Klapálek, 1912): Illies 1966: 286. (comb. n. by synonymy of Kamimuria Klapálek, 1907b with Perla Geoffroy, 1762).

Type locality. Sogon Gomba a řekou I-Čju nad Modrou Řekou; and Čerku, basin Modré Řeky, Kham, J.V. Tibet, ve výši 11400' (Sogon Gomba refers to: Qinghai Province, Yushu Tibetan Autonomous Prefecture, upper reaches of Yangtze River between Sogon Gomba monastery and I Chu River, N33 ${ }^{\circ} 35^{\prime}$ E96 $^{\circ} 35^{\prime}, 3800 \mathrm{~m}$; Čerku refers to a village close to Sogon Gomba).

Material examined. Qinghai. Yushu Tibetan Autonomous Prefecture, upper reaches of Yangtze River between Sogon Gomba temple and I Chu River, around N33 ${ }^{\circ} 35^{\prime} \mathrm{E} 96^{\circ} 35^{\prime}, 3800 \mathrm{~m}$, end of vii.1900, leg. P.K. Kozlov: 2 q syntypes (NMP, box III.11: pinned, one terminalia is in microvial) (Labels: Zwischen Sogon-Gom / ba u. d. Fl. ITschu / oberla d. Blauen Fl. / Kozlow Ende VII. 00. (handwritten); Sogon-gomba - r. / I-cju, ver. Goluboj / Kozlov. kon vii 00; amoena / Klapálek; Syntypus! / K. amoena Klp. / det. P. Zwick 1980).

Distribution. The species was described on the basis of one male and five females collected in Kham, along the upper reaches of Yangtze River. Apparently, both localities are in Qinghai Pro- 
vince, close to the border with Tibet and Sichuan Province. It was not reported since description.

Remarks. In the original description, Klapálek (1912a) stated both the Sogon Gomba (1 $\hat{O}^{1} 3$ \% $)$ and the Čerku (2P) syntypes were to be deposited in 'Mus. Cís. Akad. Petrohrad' (RAS). Two Sogon Gomba females remained in his collection and are now kept in NMP (Appendix figs. 1-2).

\section{Kamimuria brunneicornis (Klapálek, 1921)}

\section{(Appendix figures 4-5)}

Kamimuria brunneicornis (Klapálek, 1921): Sivec et al. 1988: 32. (comb. nov.); Du et al. 1999: 60. (checklist); Sivec \& Stark 2008: 137. (checklist); Stark \& Sivec 2013: 117. (checklist); DeWalt et al. 2015 (catalogue).

Marthamea brunneicornis Klapálek, 1921: Klapálek 1921: 147. (original description of female); Klapálek 1923: 102. (complementary description of female); $\mathrm{Wu} 1935$ : 303. (catalogue); Wu 1938: 62. (monography); Claassen 1940: 125. (catalogue); Illies 1966: 265. (catalogue).

\section{Type locality. Kiang-Si (Jiangxi Province).}

Material examined. Jiangxi. 1875, leg. A. David: + holotype (NMP, box VI.5: pinned, terminalia and eggs are in microvial) (Labels: 649 / $1 \mathrm{~S}$ (handwritten, last two characters illegible; circular label with yellow reverse side); Museum Paris / Kiang-Si / A. David 1875; Typus; black label; brunneicornis / Kiang-Si (handwritten); ? Kamimuria sp. / det. I. Sivec 1987 / Prirod. Muzej Slov.).

Distribution. The species is known only from the holotype from Jiangxi Province, exact locality is unknown.

Remarks. In the original description, Klapálek (1921) stated the single type was to be deposited in 'Mus. Paris' (MNHM). However, it remained in his collection and now is kept in NMP (Appendix Figs. 4-5).

\section{Kamimuria coarctata Klapálek, 1912a}

\section{(Appendix figure 6)}

Kamimuria coarctata Klapálek, 1912: Klapálek 1912a: 94. (original description of male); Klapálek 1923: 26. (complementary description of male); Wu 1935: 302. (catalogue); Wu 1938: 52. (monography); Navás 1933: 83. (first data from Zhejiang); Claassen 1940: 122. (catalogue); Zwick 1977: 116. (comb. rev. by removing Kamimuria Klapálek, 1907b from synonymy of Perla Geoffroy, 1762); Sivec et al. 1988: 32. (checklist); Zhiltzova 1995: 12. (type catalogue of RAS specimens); Du et al. 1999: 60. (checklist); Sivec \& Stark 2008: 137. (checklist); Stark \& Sivec 2013: 117. (checklist); DeWalt et al. 2015 (catalogue).

Perla coarctata (Klapálek, 1912): Illies 1966: 289. (comb. n. by synonymy of Kamimuria Klapálek, 1907b with Perla Geoffroy, 1762).

Type locality. China (without any further details) and Nord Pekin (Beijing, northern part of the city or the municipality, $\mathrm{N} 40^{\circ} \mathrm{E} 116^{\circ}$ ).

Material examined. Beijing. North Beijing, $\mathrm{N} 40^{\circ} \mathrm{E} 116^{\circ}$, 1865 , leg. A. David: Oे syntype (NMP, box III.12: pinned, abdomen without terminalia is in microvial) (Labels: Museum Paris / Nord Pekin / A. David 1865; 1473 (handwritten); 232* / $6 \mathrm{~S}$ (handwritten, last character illegible; circular label with yellow reverse side); black label; Lectotypus / K. coarctata Klap. $\hat{\delta}$ / det. P. Zwick 1980).

Distribution. The species was described on the basis of a male from the vicinity of Beijing, and a second male without exact locality data. Later, it was reported also from Zhejiang Province (Navás 1933), and there are NMP specimens from Jiangxi and Shandong Provinces. If these female specimens are indeed conspecific with the male types, the species has wide distribution in eastern China.

Remarks. In the original description, Klapálek (1912a) stated the male syntype from 'China' collected by Sjantsky was to be deposited in 'Mus. Petrohrad' (RAS), while the male syntype from Nord Pekin was to be deposited in 'Mus. Paříž' (MNHM). The latter remained in his collection and now is kept in NMP, but lacks terminalia (Appendix Fig. 6). The female of this species has never been described. However, there are two females in the NMP, pinned next to the male syntype. One of these has a locality label: Museum Paris / Kiang-Si / A. David 1878 (Jiangxi Province); but lacks an identification label. The 
another one has a locality label: Kiautschau / China (Shandong Province, Jiaozhou); and was identified by P. Zwick in 1980 .

\section{Kamimuria fulvescens Klapálek, 1912a}

(Figures 1-14)

Kamimuria fulvescens Klapálek, 1912: Klapálek 1912a: 89. (original description of male and female); Klapálek 1923: 23. (complementary description of male and female, first record from Shaanxi); Wu 1935: 302. (catalogue); Claassen 1940: 122. (catalogue); Zwick 1977: 116. (comb. rev. by removing Kamimuria Klapálek, 1907b from synonymy of Perla Geoffroy, 1762); Sivec et al. 1988: 32. (synonymy of $K$. latior Klapálek, 1912a with $K$. fulvescens); Zhiltzova 1995: 12. (type catalogue of RAS specimens); Du et al. 1999: 60. (species incertae sedis); Du \& Sivec 2005: 44. (first record from Gansu); Sivec \& Stark 2008: 137. (checklist); Stark \& Sivec 2013: 117. (checklist) DeWalt et al., 2015 (catalogue).

Perla fulvescens (Klapálek, 1912): Illies 1966: 290. (comb. n. by synonymy of Kamimuria Klapálek, 1907b with Perla Geoffroy, 1762).

Kamimuria flavescens Klapálek, 1912 (misspelling): Wu 1935: 55. (monography).

Kamimuria latior Klapálek, 1912: Klapálek 1912a: 91. (original description of female); Klapálek 1923: 24. (complementary description of female); Wu 1935: 303. (catalogue); Claassen 1940: 122. (catalogue); Kimmins 1946: 740. (first record from Tibet); Zwick 1977: 116. (comb. rev. by removing Kamimuria Klapálek, 1907b from synonymy of Perla Geoffroy, 1762).

Perla latior (Klapálek, 1912): Illies 1966: 290. (comb. n. by synonymy of Kamimuria Klapálek, 1907b with Perla Geoffroy, 1762).

Type locality. Si-Čuan, Tacienlu and Mou-Pin (Sichuan; Tacienlu refers to: Garzê Tibetan Autonomous Prefecture, Kangding County, Lucheng, N30 ${ }^{\circ} 102^{\circ}$; Mou-Pin refers to: Ya'an City, Baoxing County, Baoxing, $30^{\circ} 22^{\prime} \mathrm{N} 102^{\circ}$ 49', $1000 \mathrm{~m}$ ).

Material examined. Sichuan. Garzê Tibetan Autonomous Prefecture, Kangding County, Lucheng, N30 ${ }^{\circ} 102^{\circ}$, 20.vi.1893, leg. G.N. Potanin: $1 \delta^{\lambda} 1$ ㅇ syntypes (NMP, box III.11: pinned, both terminalia are in microvial, three eggs are prepared for SEM) (Labels (Fig. 1): Sicuan, / Taczinlu. / Potanin 20.VI93; fulvescens / Klapálek; Cotype).
Description. Adult habitus (Figs. 1-4). Large sized species, general colour pale brown. Head pale brown with brown areas posterior to M-line and occiptal suture. Tentorial callosities and $\mathrm{M}$ line distinct; a wrinkle presents between M-line and the lateral margins. Eyes and ocelli are small; distance between posterior ocelli about one and half times diameter of one ocellus. Antennae darker than head. Pronotum square, anterior edges slightly angled; narrower than head with eyes. Its ground colour pale brown, with prominent, darker rugosities. Meso- and metanotum brown. Legs pale brown, wings hyaline, veins brown. Abdomen pale, only the male hemiterga are brown.

Male terminalia (Figs. 5-6). Abdominal segments are covered with soft and pale hairs. Tergum 9 with well delimited mesal lobe that is wider than one third of segment width, and starts from midlength. Sensilla basiconica covers all the lobe; sensillae are mixed with hairs, stout and short on all of the mesal field. Tergum 10 basally deeply cleft, hemiterga half as long as segment length at lateral sides; blunt and bent inwards in dorsal view, basally down-curved while apex bent up in lateral view. Hemiterga bear sensilla basiconica apically and introbasally, covered with fine and pale hairs. Epiproct basally well sclerotized, rounded and setose; paraproct blunt. Cercus long, covered with moderately long setae, each segment bears at least one stronger ventral seta.

Aedeagus (Figs. 8-10). Membranous with a medially subdivided, ventrobasal sclerotized plate. Apically to basal sclerite the aedegus is widened in dorsal view, being the widest at basal third, then gradually tapering; laterally, it is slightly bent ventrad from midlength. Basal portion bald, first sparse spinules occur medioventrally about fourth of aedeagus length. field of spinules become denser from midlength and spread laterally; spinules form a complete ring before apical third. The apical third is covered with larger spines, except bald dorsal surface and complete subapical spine row. The apex is bald around opening.

Female terminalia (Fig. 7). Sterna and terga simple and pale, sternum 8 bears large subgenital plate. The plate is triangular but with apex dis- 

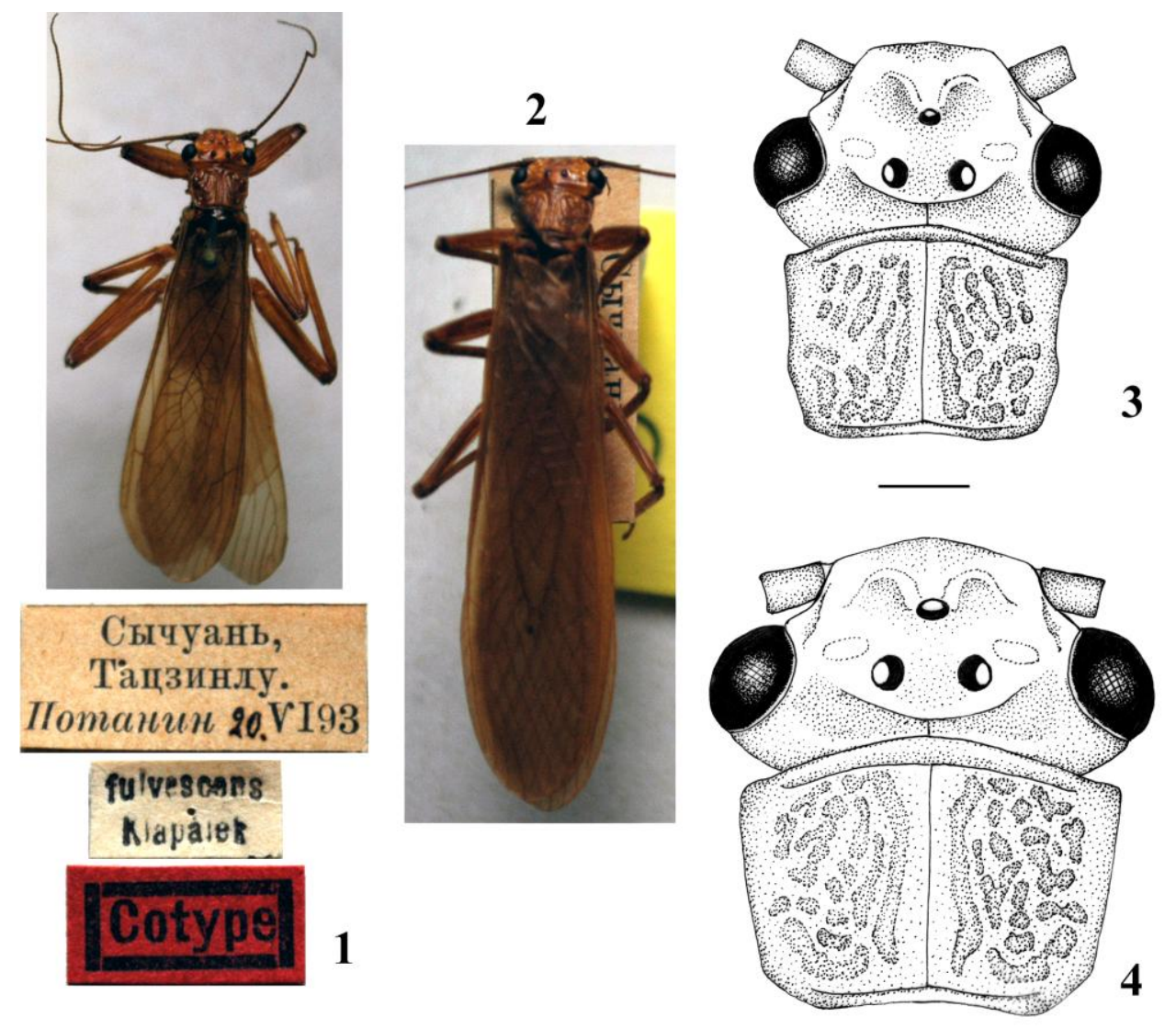

Figures 1-4. Kamimuria fulvescens Klapálek, 1912a, habitus of syntypes. 1 = habitus of male syntype, and its original labels; 2 = habitus of female syntype; 3 = head of male syntype, dorsal view; 4 = head of female syntype, dorsal view. Scale $1 \mathrm{~mm}$, Figs. 1-2 not to scale.

tinctly notched; width more than half of segment width, slightly overhanging sternum 9 . Sternum 7 and the subgenital plate covered with strong setae mixed with fine hairs, remainder of sternum 8 , and sterna 9-10 clothed only with fine hairs. Vagina simple, membranous. Epiproct and paraprocts are blunt, cercus long.

Egg (Figs. 11-14). Chorion dark brown, 0.40$0.45 \mathrm{~mm}$ long and $0.25-0.30 \mathrm{~mm}$ wide $(\mathrm{N}=3)$. Barrel shaped with pointed opercular end, cross section round. Hatching line inconspicuous. Micropyles with slightly raised rim, placed in a transverse row closer to the opercular end. Collar with raised and flanged rim, surrounded by an elongated row of FCIs; anchor not studied. Chorion is smooth in the medial third, opercular and collar end bear rows of hexagonal FCIs. Those on the opercular end with low rim with higher rim on collar end; all bear fine punctations within impression.

\section{Larva. Unknown.}

Affinities. The habitus and male terminalia are similar to many other member of the species group characterized by short hemiterga (e.g. $K$. klapaleki (Wu \& Claassen 1934), K. brevilata Du, 2002 (in: Du \& Ran 2002), K. liui Wu, 1940 (sensu Sivec 1981), K. obtusa Sivec \& Stark, 2008). Distinctive characters of the male are the large basal sclerite of aedeagus combined with the shape and arrangement of aedeagal spines. The female has an elongate egg that is rather unusual in the genus. Apparently, the closest related species are $K$. brevilata (known only from Guizhou) and $K$. klapaleki (known only from Sichuan), both have a similarly built terminalia and aedeagus. Kamimuria fulvescens can be distinguished from 
these two species by absence of swollen hemiterga and a more subtly curved aedeagus that bears more apical spines. One of us (WHL) examined the holotype of $K$. klapaleki kept in the United States National Museum, Washington (USNM). It also has the distinctive basal sclerite of the aedeagus, although this character was not illustrated or mentioned by Sivec \& Stark, 2008.

Distribution. The species seems to be widely distributed in the mountainous areas of Central
China. It was described from Sichuan Province, later reported also from Shaanxi and Gansu Provinces (Klapálek 1923, Du \& Sivec 2005). Kamimuria latior Klapálek, 1912, a species regarded as synonymous with $K$. fulvescens (Sivec et al. 1988) was described from female syntypes collected in Qinghai Province part of Kham (close to the border with Tibet and Sichuan) and an additional female from the Helan Mts. (border range between Inner Mongolia and Ningxia), later reported also from Tibet (Kimmins 1946).
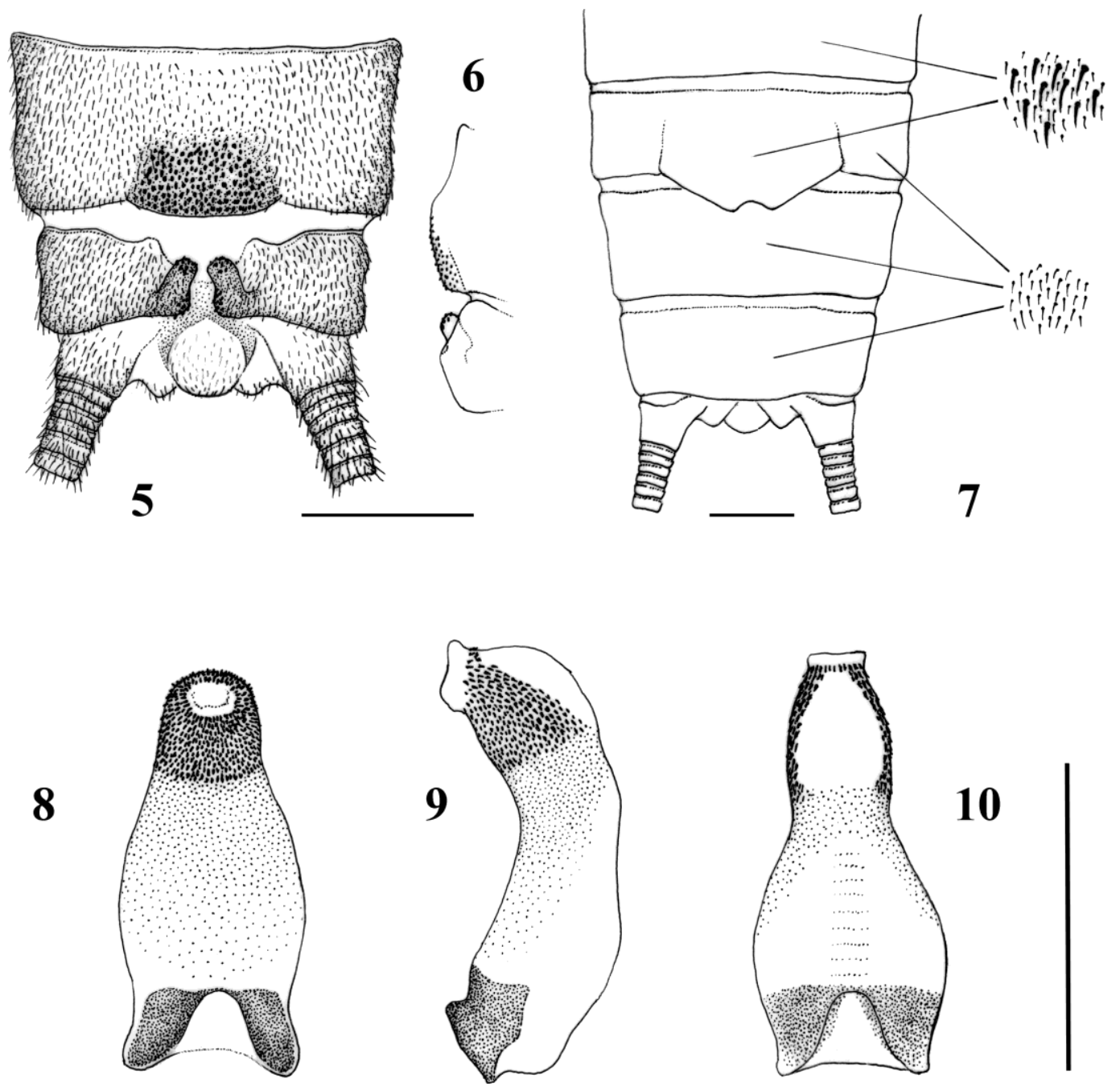

Figures 5-10. Kamimuria fulvescens Klapálek, 1912a, terminalia of syntypes. 5 = terminalia of male syntype, dorsal view; $6=$ terga $9-10$ of male syntype, lateral view (setation omitted); $7=$ terminalia of female syntype, ventral view with details of setation enlarged; $8=$ aedeagus of male syntype, ventral view; $9=$ aedeagus of male syntype, lateral view; $10=$ aedeagus of male syntype, dorsal view. Scales $1 \mathrm{~mm}$. 


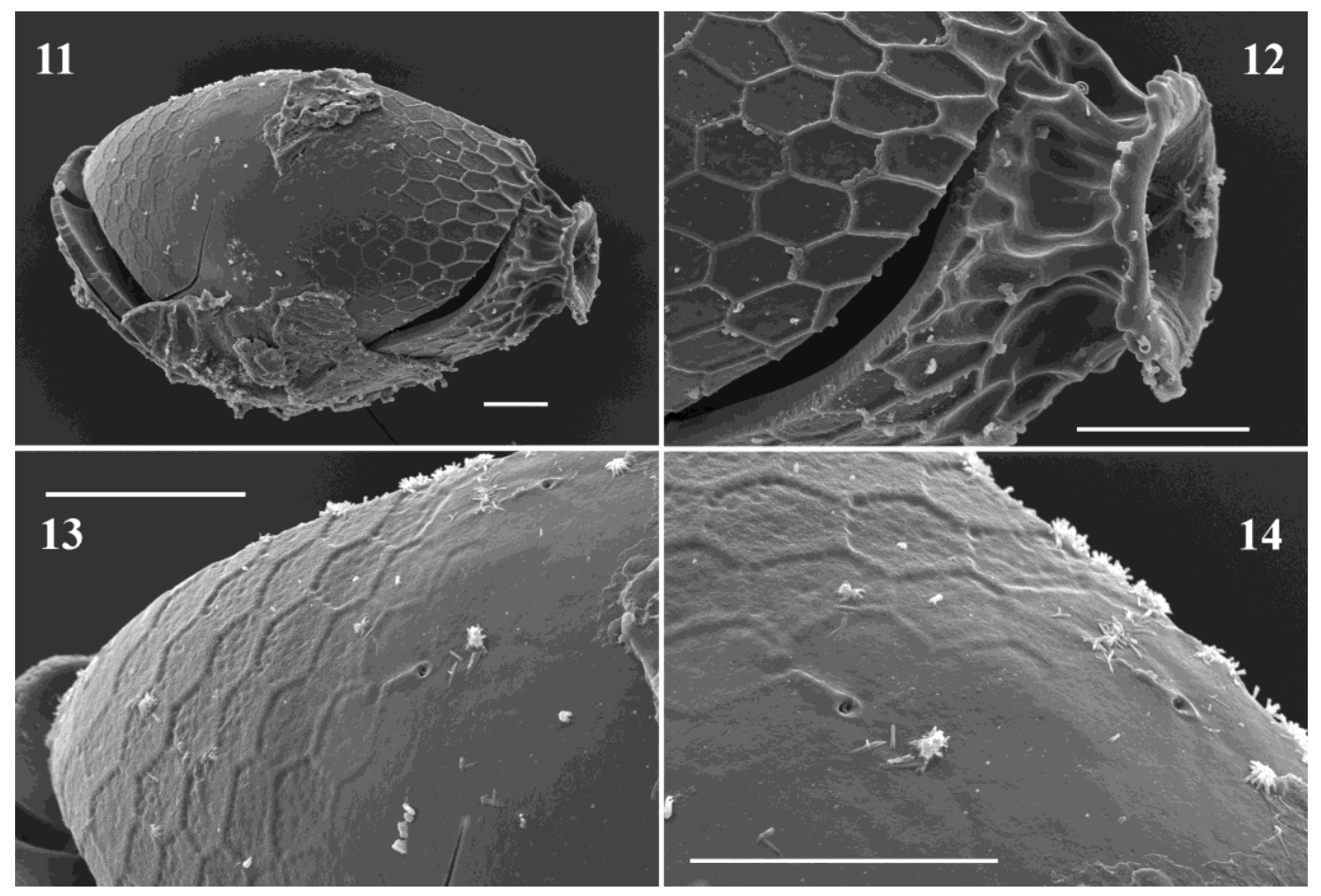

Figures 11-14. Kamimuria fulvescens Klapálek, 1912a, egg of female syntype. 11 = egg, lateral view; 12 = collar end, lateral view; $13=$ opercular end, lateral view; $14=$ micropyles. Scales $0.05 \mathrm{~mm}$.

Remarks. In the original description, Klapálek (1912a) stated the unspecified number of syntypes from Tacienlu was to be deposited in 'Mus. Petrohrad' (RAS), whereas the two syntypes from Mou-Pin were to be deposited in 'Mus. Paříž' (MNHM). Two RAS specimens remained in his collection and are now kept in NMP (Figs. 1-2), while in the MNHM three syntypes exist from Mou-Pin (according to a handwritten list received from Prof. Richard W. Baumann, Provo, USA). Klapálek (1923) also mentioned three Mou-Pin specimens.

\section{Kamimuria integra (Klapálek, 1916)}

(Appendix figure 3)

Paragnetina integra Klapálek, 1916: Klapálek 1916: 102. (original description of female); Wu 1935: 305. (catalogue); Wu 1938: 81. (monography); Claassen 1940: 130. (catalogue); Illies 1966: 496. (nomen oblitum).

Kamimuria integra (Klapálek, 1916): Sivec et al. 1988: 32. (comb. nov.); Du et al. 1999: 60. (checklist); Sivec \& Stark 2008: 137. (checklist); Stark \& Sivec 2013: 117. (checklist); DeWalt et al. 2015 (catalogue).
Type locality. Lanchovfu, Kansu (Gansu, Lanzhuo, N3603' E10350').

Material examined. Gansu. Lanzhou, $\mathrm{N}^{\circ} 6^{\circ} 03^{\prime}$ E10350': क holotype (NMP, box I.10: pinned, terminalia is in microvial) (Labels: Lanchowfu / Kansu; number; Typus; Typus; Paragnetina / integra / Klapálek det; ? Kamimuria sp. / det. I. Sivec 1987 / Prirod. muzej Slov.).

Distribution. The species is known only from the holotype from Gansu Province (Appendix Fig. $3)$.

\section{Kamimuria kelantonica Klapálek, 1912a}

Kamimuria kelantonica Klapálek, 1912: Klapálek 1912a: 95. (original description of male); Klapálek 1923: 28. (complementary description of male); Banks 1931: 377. (new record from Malaysia, Pahang State); Claassen, 1940: 122. (catalogue); Weidner 1962: 108. (type catalogue of ZMH specimens); Zwick 1977: 116. (comb. rev. by removing Kamimuria Klapálek, 1907b from synonymy of Perla Geoffroy, 1762); Sivec et al. 1988: 32. 
(checklist); Sivec \& Stark 2008: 137. (checklist); DeWalt et al, 2015 (catalogue).

Perla kelantonica (Klapálek, 1912): Illies 1966: 290. (comb. n. by synonymy of Kamimuria Klapálek, 1907b with Perla Geoffroy, 1762); Jewett 1975: 132. (first record from Thailand;

Non Kamimuria kelantonica Klapálek, 1912: Jewett 1975 = Kamimuria trang Sivec \& Stark, 2008.

Type locality. Kelanton, Vých. Malakka (Malaysia, Kelantan State, $\mathrm{N}^{\circ}{ }^{\circ} 5^{\prime} \mathrm{E} 102^{\circ}$ ).

Material examined. Malaysia. Kelantan State, $\mathrm{N} 5^{\circ} 15^{\prime}$ E102 ${ }^{\circ}$ : $2{ }^{\Uparrow}$ (NMP, box III.12: pinned, both terminalia are in microvial) (Labels: Kelanton / Malakka; Kamimuria / kelantonica Klp. / det. Sivec 1987 (handwritten)).

Distribution. The species was described on the basis of a single male from Kelantan State. Later, it was reported from neighbouring Pahang State (Banks 1931) of peninsular Malaysia. Specimens from Thailand (Jewett 1975) proved to be $K$. trang Sivec \& Stark, 2008. To date, this is the southernmost distributed member of the genus.

Remarks. In the original description, Klapálek (1912a) stated the male holotype was to be deposited in 'Mus. Hamburg' (Zoologischen Museums Hamburg, ZMH). According to the type catalogue of Weidner (1962), the ZMH indeed received it. However, there are two additional males in the NMP from the same locality, although neither have a type or original identification label. Jewett (1975) published Thailand data of the species based on specimens held in the National Museum of Natural History, Washington D.C. (USNM) and California Academy of Sciences (CAS), all from Trang Province. The USNM specimens proved to be $K$. trang Sivec \& Stark, 2008, but the identity of the CAS specimens is questionable.

\section{Kamimuria latior Klapálek, 1912a}

(Appendix figure 7)

Synonymy detailed under Kamimuria fulvescens Klapálek, 1912a.
Type locality. Mezi Sogon Gomba a řekou IČju, na horním toku Modré Řeky; Darindo při horním toku Modré Řeky; and Již. Alašan, Gobi (Sogon Gomba refers to Qinghai Province, Yushu Tibetan Autonomous Prefecture, upper reaches of Yangtze River between Sogon Gomba monastery and I Chu River, N33 $35^{\prime}$ E96 ${ }^{\circ} 5^{\prime}, 3800 \mathrm{~m}$; Darindo refers to a village close to Sogon Gomba; Již. Alašan refers to southern part of the Helan Mountains that borders between Inner Mongolia Autonomous Region and Ningxia Hui Autonomous Region).

Material examined. Qinghai. Yushu Tibetan Autonomous Prefecture, upper reaches of Yangtze River, Darindo village, N33 E96 ${ }^{\circ}$, 1-3. viii.1900, leg. P.K. Kozlov: 19 syntype (NMP, box III.11: pinned, terminalia is in microvial) (Labels: Umgebung des Ortes / Darindo, oberlauf / d. Blauen Fl., Kham. / S-O. Tibet Kozlow 1/3 VIII. 00. (handwritten); okr. ur. Darindo / Kam, ver. Goluboj / Kozlov. 1/3 viii 00; latior / Klapálek; Cotype).

Remarks. In the original description, Klapálek (1912a) stated all the syntypes (Sogon Gomba: 1ㅇ, Darindo: 2 , Alašan: 1ㅇ) were to be deposited in 'Museu cís. Akademie v Petrohradě' (RAS). One of the Darindo females remained in his collection and is now kept in NMP (Appendix Fig. 7). Sivec et al. (1988) regarded this species to be synonymous with $K$. fulvescens. As the syntypes came from localities rather far from each other, we avoid judging this opinion on the basis of the single NMP specimen.

\section{Kamimuria lepida Klapálek, 1913}

(Figures 15-21)

Kamimuria lepida Klapálek, 1913: Klapálek 1913: 112. (original description of male); Klapálek 1923: 34. (complementary description of male); Claassen 1940: 123. (catalogue); Zwick 1977: 116. (comb. rev. by removing Kamimuria Klapálek, 1907b from synonymy of Perla Geoffroy, 1762); Petersen \& Gaedike 1968: 966. (type catalogue of DEI specimens); Sivec et al. 1988: 32. (checklist); Du et al. 1999: 61. (checklist); Sivec \& Yang 2001: 402. (checklist); Sivec \& Stark 2008: 137. (checklist); DeWalt et al. 2015 (catalogue). 
Perla amoena (Klapálek, 1912): Illies 1966: 291. (comb. n. by synonymy of Kamimuria Klapálek, 1907b with Perla Geoffroy, 1762).

Type locality. Formosa, Suisharyo (Taiwan, Chiayi County, Alishan Mts., Shui, N2331' E120 48').

Material examined. Taiwan. Taipei City, $\mathrm{N} 25^{\circ}$ 02' E12131', 07.iv.1912, leg. H. Sauter: $1{ }^{\Uparrow}$ (NMP, box VI.6: pinned, terminalia is in microvial) (Labels: Taihoku / Formosa / H. Sauter, 1912; 7.IV.; Kamimuria / lepida Klp. / Klapálek det. (handwritten); Cotype; K. lepida (handwritten, by I. Sivec)).
Description. Adult habitus (Figs. 15-16). Medium sized species, general colour pale brown. Head pale brown in the occipital area, with dark brown patches around the ocelli, and brown anterior to the M-line. Tentorial callosities and $\mathrm{M}$ line distinct; a wrinkle present between M-line and the lateral margins. Eyes and ocelli are large; distance between posterior ocelli about twice diameter of one ocellus. Antennae darker than head. Pronotum square, anterior edges slightly angled; narrower than head with eyes. Its ground colour brown, with prominent, darker rugosities. Mesoand metanotum brown. Legs pale brown, wings hyaline, veins brown. Abdomen pale, only the hemiterga are brown.

\section{5}
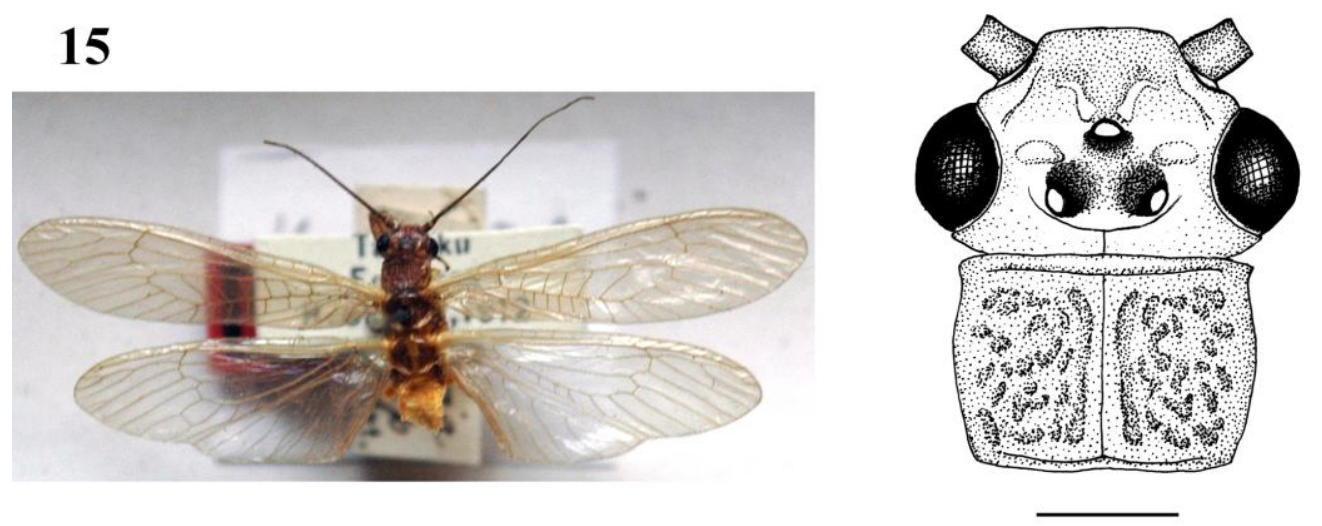

16
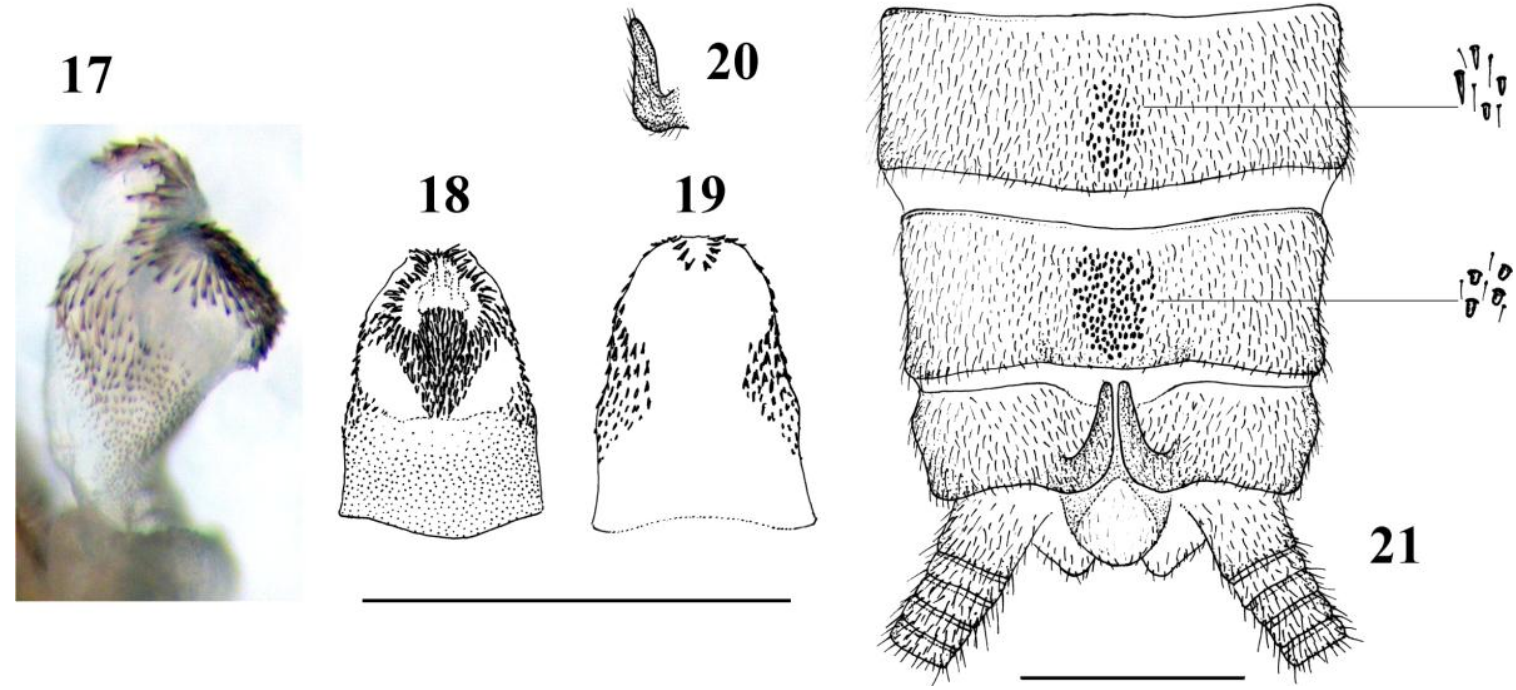

Figures 15-21. Kamimuria lepida Klapálek, 1913 male. $15=$ habitus; $16=$ head, dorsal view; $17=$ aedeagus, lateral view; $18=$ aedeagus, ventral view; $19=$ aedeagus, dorsal view; $20=$ hemitergum 10 , lateral view; $21=$ terminalia, dorsal view with details of sensilla basiconica enlarged. Scales $1 \mathrm{~mm}$, Figs. 15,17 not to scale. 
Male terminalia (Figs. 20-21). Abdominal segments are covered with soft and pale hairs. Sterna 6-7 with hair brushes, lateral combs are on the lateroapical edge of segments 8-9. Tergum 8 with narrow mesal field of sensilla basiconica; sensillae are mixed with hairs, slim and elongated, basal ones are acute. Tergum 9 with hardly delimited mesal lobe, sensilla basiconica covers medial fourth of the segment nearly from its base to apex; sensillae are mixed with hairs, stout and short on all of the mesal field. Tergum 10 basally hardly cleft, hemiterga as long as segment length, finger-like; straight and pointed in dorsal view, apex slightly bent up in lateral view. Hemiterga bear no sensilla basiconica, but covered with fine and pale hairs. Epiproct basally well sclerotized, rounded and setose; paraproct blunt. Cercus long, covered with moderatelly long setae, each segment bears at least one stronger ventral seta.

Aedeagus (Figs. 17-19). Membranous, apex with a dorsal lobe that is expanded upwards. Basal portion covered with spinules ventrally and laterally, dorsal surface bald. Mediolaterally, spines gradually increase in size; these fields are connected to the large and elongated, rose-thorn shaped spines of the apical portion. These spines form a V-shaped field on the ventral surface, that is continued in a medioventral stripe to the opening of the aedeagus. Laterally, these spines surround the opening and join on the dorsal apex of the dorsal lobe.

Female, larva and egg. Unknown.

Affinities. The habitus and male terminalia are similar to many other members of the genus, although the apically bent-up hemiterga is rare within the Kamimuria species with long hemiterga (e.g. K. hainana Li et al., 2012, K. atra Sivec \& Stark, 2008, K. tuberosa Wu, 1973). However, the peculiar setation of the short aedeagus is distinctive. Apparently, the closest related species is $K$. hainana (endemic to Hainan Island) that has similarly built terminalia and aedeagus, but the two species can be easily distinguished by the less numerous large spines that are restricted to the apex of the aedeagus of $K$. hainana.
Distribution. The two male syntypes were collected in the Alishan Ranges of Central Taiwan, while the NMP specimen is from the north of the island. Most probably endemic to Taiwan.

Remarks. In the original description, Klapálek (1913) did not state the depository of the two male syntypes. However, they are held in the Deutschen Entomological Institutes (DEI), like most of his specimens published from Taiwan (Petersen \& Gaedike 1968). The NMP male is not a type, even though it bears a 'Cotype' label (Fig. 15), but it was originally identified by Klapálek before the publication.

\section{Kamimuria quadrata (Klapálek, 1907b)}

\section{(Appendix figure 8)}

Perla (Kamimuria) quadrata Klapálek, 1907: Klapálek 1907b: 15. (original description of male and female); Klapálek 1907c: 266. (German translation of the original description).

Kamimuria quadrata (Klapálek, 1907): Klapálek 1912a: 86. (key); Okamoto 1912: 119. (key); Klapálek 1923: 24. (complementary description of male and female); Kohno 1937: 92. (description of larva); Claassen 1940: 123. (catalogue); Uéno \& Okamoto 1950: 84. (illustrations on the imago); Uéno 1959: 37. (illustration on the larva); Kawai 1967: 133. (monograph); Zwick 1977: 116. (comb. rev. by removing Kamimuria Klapálek, 1907b from synonymy of Perla Geoffroy, 1762); Sivec et al. 1988: 32. (checklist); Isobe 1988: 35. (description of egg); Uchida 1990: 183. (monograph); Isobe 1997: 359. (complementary description of egg); Sivec \& Stark 2008: 137. (checklist); DeWalt et al. 2015 (catalogue).

Perla quadrata (Klapálek, 1907): Illies 1966: 294. (comb. n. by synonymy of Kamimuria Klapálek, 1907b with Perla Geoffroy, 1762).

Type locality. Japan (without any further details) and Oiwaki (probably Oiwake, a former town merged into Abira, Yūfutsu (Iburi) District of Hokkaido, N4246’ E141²4').

Material examined. Japan. Oiwaki, (probably Oiwake, a former town merged into Abira, Y $\overline{\mathrm{u}}-$ futsu (Iburi) District of Hokkaido, N42 ${ }^{\circ} 46^{\prime}$ E141 $\left.{ }^{\circ} 49^{\prime}\right)$ : $1{ }^{\top}$ syntype (NMP, box III.12: pinned) (Labels: 57 (handwritten); Oiwaki / Mus. Bruxell (handwritten); Collect / Klapálek / quadrata / Klapálek). 
Distribution. The species was described on the basis of two male and one female syntypes from Oiwaki (probably Hokkaido) and a second female syntype without exact locality from 'Japan'. Since then it was discovered to be widespread on Hokkaido and Honshu, and is found also on Oki Isles of Japan (Uchida 1990).

Remarks. In the original description, Klapálek (1907b) stated the female syntype from 'Japan' was to be deposited in 'museum Berlinské' (Museum für Naturkunde Berlin, RAS), while the two male and one female syntypes from Oiwaki were to be deposited in 'mus. Brusselské' (Royal Belgian Institute of Natural Sciences, RBINS). A male from the latter remained in his collection and is now kept in NMP (Appendix Fig. 8).

\section{Kamimuria sikkimensis (Enderlein, 1909)}

Perla sikkimensis Enderlein, 1909: Enderlein 1909: 349. (original description of female); Claassen 1940: 145. (catalogue); Illies 1966: 508. (nomen dubium); Zwick 1973: 494. (complementary description of female, questioning generic identity).

Kamimuria sikkimensis (Enderlein, 1909): Sivec et al. 1988: 33. (comb. n.); Sivec \& Stark 2008: 137. (checklist); DeWalt et al. 2015 (catalogue).

Type locality. Sikkim (India, Sikkim State).

Material examined. India. Sikkim State: $3 q$ (NMP, box VIII.16: pinned) (Labels: Sikkim; Plesiotypus - under one of the specimens: Sikkim / Hag. (handwritten, instead of printed 'Sikkim' label of the other two specimens)).

Distribution. The species is known only from the holotype from Sikkim State and the exact locality is unknown. The three NMP specimens also lacks further details about their locality.

Remarks. The three NMP females are pinned next to a label: Acroneuria sikkimensis End., but lack individual identification labels. Apparently, Klapálek didn't publish this combination, although the specimens bear 'Plesiotypus' labels, indicating that he was about to redescribe the taxon on the basis of these specimens. However, the generic identity of these NMP specimens are unsure, but probably they are not Kamimuria.

\section{Kamimuria similis Klapálek, 1912a}

(Figures 22-25, Appendix figures 9-10)

Kamimuria similis Klapálek, 1912: Klapálek 1912a: 101. (original description of male); Klapálek 1923: 33. (complementary description of male); Wu 1935: 303. (catalogue); Wu 1938: 59. (monography); Claassen 1940: 124. (catalogue); Zwick 1977: 116. (comb. rev. by removing Kamimuria Klapálek, 1907b from synonymy of Perla Geoffroy, 1762); Sivec et al. 1988: 33. (checklist); Du et al. 1999: 61. (checklist); Sivec \& Stark 2008: 123. (redescription of male); DeWalt et al. 2015 (catalogue).

Perla similis (Klapálek, 1912): Illies 1966: 294. (comb. n. by synonymy of Kamimuria Klapálek, 1907b with Perla Geoffroy, 1762).

Type locality. Frontière China-Tonkin, region de Laokay, et Ho-Kheou (Laokay refers to: Vietnam, Lào Cai Province, Lào Cai, while Ho-Kheou refers to: China, Yunnan Province, Hekou Yao Autonomous County; coordinates of the border crossing Hekou-Lào Cai bridge are N22 $30.4^{\prime}$ E10357.8', 80m).

Material examined. Vietnam-Yunnan border. Lào Cai Province - Hekou Yao Autonomous County, Hekou-Lào Cai bridge, N22 ${ }^{\circ} 30.4^{\prime}$ E103 ${ }^{\circ}$ 57.8', 80m, 1900, leg. C. Dupont: $\overbrace{}^{\lambda}$ holotype (NMP, box VI.6: pinned, terminalia is in microvial) (Labels: Museum Paris / Frontière Chine-Tonkin / Région de Lao-Kay / et Ho Kheou / Ch. Dupont 1900; black label; Holotypus / K. similis Klp. / det. P. Zwick 1980 (handwritten)).

Distribution. The species is known only from the holotype from the border of Vietnam and China.

Remarks. In the original description, Klapálek (19012a) stated the male holotype was to be deposited in 'Mus. Paris' (MNHN), however, it remained in his collection and now is kept in NMP (Appendix figs. 9-10). The terminalia and aedeagus were recently described in detail by Sivec $\&$ Stark (2008), but they had no access to the rest of the body. Herein we figure the distinct bicoloured head (Fig. 22), and present photos of the aedeagus to show the large basal sclerite (Figs. 23-25) that was not shown by Sivec \& Stark (2008). In the NMP, there is a further specimen pinned next to 
the holotype, from China, Chen-Si (Shaanxi Province), 1875, leg. A. David. This specimen was mentioned in the original description (Klapálek 1912a) as similar to $K$. similis and $K$. praeusta (now in Agnetina), but not included in either description. Later, in the monograph of the Perlinae (Klapálek 1923), this specimen was not mentioned. Now it lacks terminalia, and apparently is not conspecific, in all probability not even congeneric with the $K$. similis type.

\section{Kamimuria tibialis (Pictet, 1841)}

Perla tibialis Pictet, 1841: Pictet 1841: 217. (original description of imago); Walker 1852: 151. (catalogue); McLachlan, 1875: 171. (complementary description of imago); Jakobson \& Bianki 1905: 616. (complementary description of male and female); Uéno 1929: 109. (description of larva); Illies 1966: 294. (comb. n. by synonymy of Kamimuria Klapálek, 1907b with Perla Geoffroy, 1762); Zwick, 1971: 1180. (report on lack of type).

Perla (Kamimuria) tibialis (Pictet, 1841): Klapálek 1907b: 13. (complementary description of male and female); Klapálek 1907c: 265. (German translation of the complementary description).

Kamimuria tibialis (Pictet, 1841): Klapálek 1912a: 86. (key); Okamoto 1912: 119. (key); Klapálek 1923: 20, 29. (designation as type species, complementary description of male and female); Claassen 1940: 124. (catalogue); Kohno 1947: 46. (complementary description of larva); Uéno \& Okamoto 1950: 83. (illustrations on the imago); Uéno 1959: 38. (illustration on the larva); Kawai 1967: 135. (monograph); Zwick 1977: 116. (comb. rev. by removing Kamimuria Klapálek, 1907b from synonymy of Perla Geoffroy, 1762); Sivec et al. 1988: 33. (checklist); Isobe 1988: 35. (description of egg); Uchida 1990: 184. (mono graph); Uchida \& Isobe 1991: 66. (redescription, designnation of a neotype); Isobe 1997: 359. (complementary description of egg); Sivec \& Stark 2008: 137. (checklist); Teslenko \& Zhiltzova 2009: 58, 292. (monograph); DeWalt et al. 2015 (catalogue).

Type locality. Japon (Japan, without any further details).

Material examined. Japan. Honshu, Gifu Prefecture, iv-v.1886: $1 \delta^{\widehat{ }} 1$ 우 (NMP, box III.12: pinned, both terminalia are in microvial) (Labels: Gifu / ApMay (hardly legible) / 1886 (handwritten); tibialis / Klapálek; Collect / Klapálek); Honshu, Kanagawa Prefecture, Yokohama, N35 26' E139³8': 10 (NMP, box III.12: pinned, lacks terminalia) (Labels: small red label; Perla / Tibialis Pict. / Yok. (hasndwritten)).

Distribution. The species was described on the basis of specimen(s) without exact locality from Japan. It proved to be widespread on the islands from Kunashir in the north to Kyushu in the south, but seems to be missing from the Asian mainland (Uchida \& Isobe 1991, Teslenko \& Zhiltzova 2009).

Remarks. In the paper where Kamimuria was described (Klapálek 1907b), only the Yokohama specimen was mentioned. The pair from Gifu were not even mentioned in the Perlinae monography (Klapálek 1923).
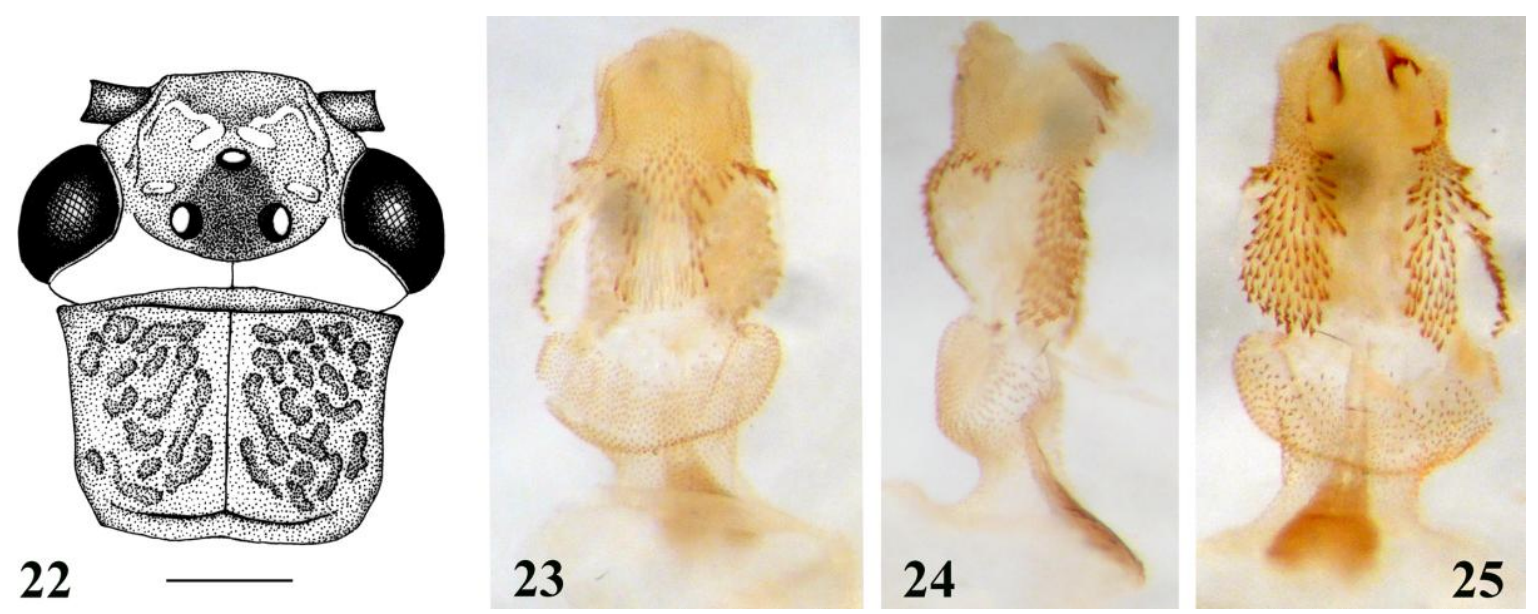

Figures 22-25. Kamimuria similis Klapálek, 1912a, male holotype. 22 = head, dorsal view; 23 = aedeagus, dorsal view; 24 = aedeagus, lateral view; $25=$ aedeagus, ventral view. Scale $1 \mathrm{~mm}$, Figs. $23-25$ not to scale. 


\section{DISTRIBUTION OF THE GENUS KAMIMURIA}

According to the latest checklists (DeWalt et al. 2015, Sivec \& Stark 2008, Stark \& Sivec 2013), there are 85 species classified recently in Kamimuria. Among these, 64 are considered valid, 4 are synonyms while 17 are nomen dubium with type specimens lost or destroyed.

The genus is confined to the Oriental and temperate East Palaearctic region (Fig. 26). Even though our knowledge is far from complete regarding both their faunistic and taxonomic details, some observations already can be made on their distribution. Apparently, the centre of their diversity is on the southern and eastern mountainous regions of the Qinghai-Tibet Plateau, from Gansu in the north southwards to Southeast Asia (lack of data from Laos and Cambodia are due to undersampling, and probably not of real absence). $\mathrm{Ka}$ mimuria are missing from the plains and inhabits mostly medium high mountains, but have been found up to 4000 meters.

Acknowledgements - We owe thanks to Pável Chvojka (NMP) for help during work in NMP and information about the Klapálek Collection's history. We are also grateful to the anonymous reviewers for comments and linguistic corrections. The research was supported by the 2013-2015 Sino-Hungarian scientific and technological cooperative projects (No. 6-33 in China, TÉT_12_CN-1-2012-0006 in Hungary) and the SYNTHESYS Project, FP7 "Capacities" Program (CZ-TAF-3636).

\section{REFERENCES}

BANKS, N. (1931): Some Neuropteroid Insects from the Malay Peninsula. Journal of the Federated Malay States Museums, 16(18): 377-409.

BASSET, C. (2009): In the footsteps of Father David. Arnoldia, 67(2): 22-28.

BoJKovÁ, J. \& SOLDÁN, T. (2013): Stoneflies (Plecoptera) of the Czech Republic: species checklist, distribution and protection status. Acta Entomologica Musei Nationalis Pragae, 53(2): 443-484.

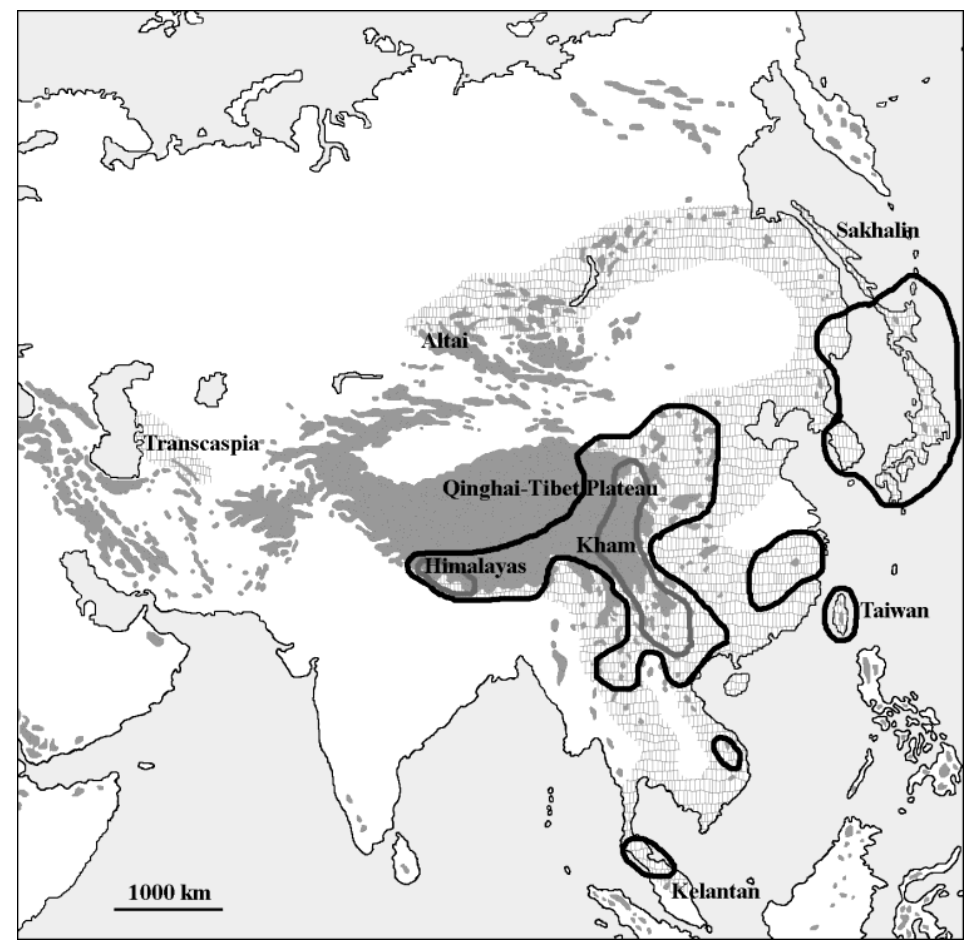

Figure 26. Distribution of the genus Kamimuria Klapálek, 1907b, with indication of geographical names important regarding occurrences. Reticulated pattern indicate areas where Kamimuria species are reportedly occur; black line deliminate areas where more than one species occur, while dark grey line deliminate areas where more than five species occur; grey areas are above 2000 meters. 
ClaAssen, P. W. (1940): A Catalogue of the Plecoptera of the World. Memoirs of the Cornell University Agricultural Experiment Station, Ithaca, 232: 1-235.

DeWalt, R. E., Maehr, M. D., Neu-Becker, U. \& Stueber, G. (2015): Plecoptera Species File Online. Ver. 5.0/5.0, http://Plecoptera.SpeciesFile.org. (accessed 06.03.2015)

DU, Y. Z. \& RAN, J. C. (2002): Plecoptera. LI, Z. Z. \& JIN, D. C. (Eds.) Insects from Maolan Landscape, Guizhou Science and Technology Publishing House, Guiyang, p. 108-117.

DU, Y. Z. \& Sivec, I. (2005): Plecoptera. YANG, X. K. (Ed.) Insect Fauna of Middle-West Qinling Range and South Mountains of Gansu Province, Science Press, Beijing, p. 38-54.

Du, Y. Z., SiVEC, I. \& HE, J. H. (1999): A checklist of the Chinese species of the family Perlidae (Plecoptera: Perloidea). Acta Entomologica Slovenica, 7: 59-67.

ENDERLEIN, G. (1909): Plecopterologische Studien II. Stettiner Entomologische Zeitung, 70: 324-352.

Geoffroy, E. L. (1762): Perla. Histoire abrégée des insectes, Vol. 2, Paris, p. 229-233.

ILLIES, J. (1966): Katalog der rezenten Plecoptera. Das Tierreich, Berlin, 82: 1-632.

IsoBE, Y. (1988): Eggs of Plecoptera from Japan. Biology of Inland Waters, 4: 27-39.

ISOBE, Y. (1997): Anchors of stonefly eggs. LANDOLT, P. \& SARTORI, M. (Eds.) Ephemeroptera \& Plecoptera: Biology-Ecology-Distribution, Mauron, Tinguely \& Lachat SA, Fribourg, p. 349-361.

JAKOBSON, G. G. \& BIANKI, V. L. (1905): VI. Vesnjanki. Plecoptera. Prjamokrilia I Lozhostchatokrilia Rossijskoi Imperii I sopredlnih stran, A. F. Devriena, Imperatorskoi Akademii Nauk, St. Petersburg, p. 502-634.

JewetT, S. G. (1975): Some stoneflies from Bangladesh, India and Southeast Asia. Oriental Insects, 9(2): 127-134.

KAWAI, T. (1967): Fauna Japonica. Plecoptera (Insecta). Biogeographical Society of Japan, Tokyo, $211 \mathrm{pp}$.

KIMMINS, D. E. (1946): New species of Himalayan Plecoptera. Annals and Magazine of Natural History, 11(13): 721-740. doi: $10.1080 / 00222934608654596$
KlaPÁleK, F. (1907a): Evropské druhy rodu Perla Geoffr. Rozpravy České Akademie císaře Františka Jozefa, 16(16): 1-25.

KLAPÁLEK, F. (1907b): Japonské druhy podčeledi Perlinae. Rozpravy České Akademie císaře Františka Jozefa, 16(31): 1-28.

KLAPÁlEK, F. (1907c): Über die Arten der Unterfamilie Perlinae aus Japan. Bulletin international de l'Académie des Sciences de Bohême, 12(31): 257274.

KLAPÁLEK, F. (1912a): Plecopterorum genus: Kamimuria Klp. Zvláštni otisk Časopisu České Společnosti Entomologické, 9(2): 84-110.

KLAPÁLEK, F. (1912b): H. Sauter's Formosa-Ausbeute Plecoptera. Supplementa Entomologica, 1(11): 342-351 + Pl. VII.

KLAPÁLEK, F. (1913): H. Sauter's Formosa-Ausbeute. Plecoptera II. Supplementa Entomologica, 2: 112 $127+$ Pl. III.

KlaPÁleK, F. (1916): Kamimuria sibirica et Paragnetina integra, Plecopterorum species novae. Časopis České Společnosti Entomologické, 13: 101-103.

KLAPÁLEK, F. (1921): Plécoptères nouveaux. I. Sousfamilie des Perlinae et Neoperlinae. Annales de la Sociétè Entomologique de Belgique, 61: 57-67.

KlapÁleK, F. (1923): Plécoptéres II. Fam. Perlidae. Subfam. Perlinae, Subfam. Neoperlinae. Collections zoologiques du baron Edm. de Sélys Lonchamps, 4(2): 1-193.

KoHNO, M. (1937): Descriptions of nymphs of Acroneuria stigmatica Klapálek and Kamimuria quadrata Klapálek. Mushi, 10: 91-95. (in Japanese)

KoHNO, M. (1947): On the larva of Kamimuria tibialis (Pictet) with a new form (Plecoptera). Matsumushi, 2: 46-51. (in Japanese)

Kozlov, P. K. (1947): Mongolia and Kham. Three years's travel in Mongolia and Tibet (1899-1901). $2^{\text {nd }}$ Edition (in Russian). Gosudarstvennoe Izdatelstvo Geograficekoi Literaturi, Moscow, 170 pp.

LI, W. H., WANG, L. H. \& YU, H. (2012): First record of Kamimuria (Plecoptera: Perlidae) from Hainan Island of China, with description of $K$. hainana $\mathrm{n}$. sp. Zootaxa, 3500: 84-88.

MCLACHLAN, R. (1875): A sketch of our present knowledge of the Neuropterous fauna of Japan (excluding Odonata and Trichoptera). Transactions 
of the Royal Entomological Society of London, 23(2): 167-190. doi: 10.1111/j.1365-2311.1875.tb01906.x

NAVÁs, L. (1933): Insecta Orientalia. XII series. Memorie dell'Accademia Pontifica dei Nuovi Lincei, Rome, 2(17): 75-108.

Окамото, H. (1912): Erster Beitrag zur Kenntnis der Japanischer Plecopteren. Transactions of the Sapporo Natural History Society, 4: 105-170.

Petersen, G. \& Gaedike, H. (1968): Katalog der in den Sammlungen des Deutschen Entomologischen Institutes aufbewahrten Typen - I. Ephemeroptera, Odonata, Plecoptera. Beiträge zur Entomologie, 18(7-8): 959-969.

PICTET, F. J. (1841): Histoire naturelle générale et particulière des insectes Névroptères. Famille des Perlides. Kessmann-Baillière, Genève-Paris, 423 pp. + Pl. I-LIII.

RAuSER, J. (1968): 67. Plecoptera. Ergebnisse der zoologischen Forschungen von Dr. Z. Kaszab in der Mongolei. Entomologische Abhandlungen Staatliches Museum für Tierkunde in Dresden, 34(5): 329-398.

SIVEC, I. (1981): Contribution to the knowledge of Nepal stoneflies (Plecoptera). Aquatic Insects, 3(4): 245-257. doi: 10.1080/01650428109361069

Sivec, I. \& Stark, B. P. (2008): New species of Kamimuria Klapálek (Plecoptera: Perlidae) from Thailand and Vietnam, with notes on Chinese species. Illiesia, 4(12): 110-138.

Sivec, I., Stark, B. P. \& UchidA, S. (1988): Synopsis of the World Genera of Perlinae (Plecoptera: Perlidae). Scopolia, 16: 1-66.

Sivec, I. \& YANG, P. S. (2001): Stoneflies of Taiwan within the Oriental stonefly fauna diversity. DomingueZ, E. (Ed.) Trends in research in Ephemeroptera and Plecoptera. Kluwer Academic Plenum Publishers, New York, Boston, Dordrecht, London, Moscow, p. 401-404.

STARK, B. P. \& SiVEC, I. (2013): Kamimuria gressitti, a new stonefly species from China (Plecoptera: Perlidae), and new records of $K$. atra from Vietnam. Illiesia, 9(11): 116-121.

Teslenko, V. A. \& Zhiltzova, L. A. (2009): Key to the stoneflies (Insecta, Plecoptera) of Russia and adjacent countries. Imagines and nymphs. Russian Academy of Sciences, Dalnauka, Vladivostok, 382 pp.
UCHIDA, S. (1990): A revision of the Japanese Perlidae (Insecta: Plecoptera), with several reference to their phylogeny. PhD Thesis, Tokyo Metropolitan University, Tokyo, $228 \mathrm{pp}$.

UCHIDA, S. \& IsobE, Y. (1991): Designation of a neotype for Kamimuria tibialis (Pictet, 1841), and K. uenoi Kohno, 1947, spec. propr., stat. n. (Plecoptera: Perlidae). Aquatic Insects, 13(2): 6577. doi: $10.1080 / 01650429109361426$

UChIDA, S., Stark, B. P. \& SiveC, I. (2011): Xanthoneuria, a new genus of stonefly (Plecoptera: Perlidae) from Japan. Illiesia, 7(5): 65-69.

UÉNO, M. (1929): Studies on the stoneflies of Japan. Memoirs of the College of Science, Kyoto Imperial University, Series B, 4(2): 97-155 + Pl. XXIV.

UÉNO, M. (1959): Plecoptera. Illustrated Insect larvae of Japan, Tokyo, p. 28-42.

UÉNO, M. \& OKAмото, H. (1950): Plecoptera. Iconographia Insectorum Japonicum, Hokuryukan, Tokyo, p. 75-86.

Walker, F. (1852): Sub-order 2. Perlides. Catalogue of the specimens of Neuropterous Insects in the collection of the British Museum. Part I. (Phryganides-Perlides). Edward Newman, London, p. 136-192.

WEIDNER, H. (1962): Die entomologischen Sammlungen des Zoologischen Staatsinstitutes und Zoologischen Museums Hamburg. IV. Teil, Insecta I. Mitteilungen aus dem Hamburgischen Zoologischen Museum und Institut, 60: 81-109.

Wu, C. F. (1935): Order IX. Plecoptera. Catalogus Insectorum Sinensium, Vol. 1, Fan Memorial Institution of Biology, Peiping, p. 299-315.

WU, C. F. (1938): Plecopterorum sinensium: A monograph of stoneflies of China (Order Plecoptera). Yenching University, Beijing, 225 pp. + Pl. IXLVII.

WU, C. F. (1940): Second supplement to the stoneflies of China (Order Plecoptera). Peking Natural History Bulletin, 14(4): 331-333.

WU, C. F. (1973): New species of Chinese stoneflies (Order Plecoptera). Acta Entomologica Sinica, 16(2): 111-118 + Pl. I-VIII.

Wu, C. F. \& ClaAssen, P. W. (1934): Aquatic Insects of China. Article XVIII. New species of Chinese stoneflies (Order Plecoptera). Peking Natural History Bulletin, 9(2): 111-129. 
Zhiltzova, L. A. (1995): Katalog tipovyh ekzemplyarov kollektsii zoologicheskogo instituta RAN. Vesnyanki (Plecoptera). SPB, St. Petersburg, 37 pp.

ZWICK, P. (1971): Die Plecopteren Pictets und Burmeisters, mit Angaben über weitere Arten (Insecta). Revue Suisse de Zoologie, 78(4): 11231194.

ZWICK, P. (1973): Die Plecopteren-Arten Enderleins (Insecta); Revision der Typen. Annales Zoologici, 30(16): 471-507.
ZWICK, P. (1977): Ergebnisse der Bhutan-Expedition 1972 des Naturhistorischen Museums in Basel. Plecoptera. Entomologica Basiliensia, 2: 85-134.

ZWICK, P. (1982): The Stonefly Collection of F. Klapálek in Prague, with notes on the Nemouridae (Plecoptera). Aquatic Insects, 4(1): 39-48. doi: $\underline{10.1080 / 01650428209361077}$

ZWICK, P. (1983): The Neoperla of Sumatra and Java (Indonesia) (Plecoptera: Perlidae). Spixiana, 6(2): 167-204. 


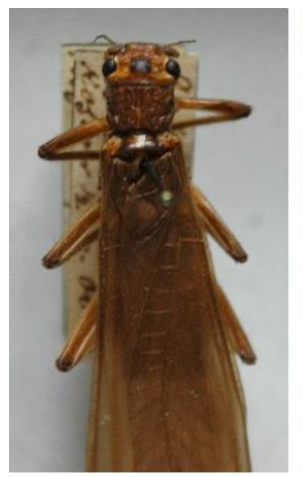

1

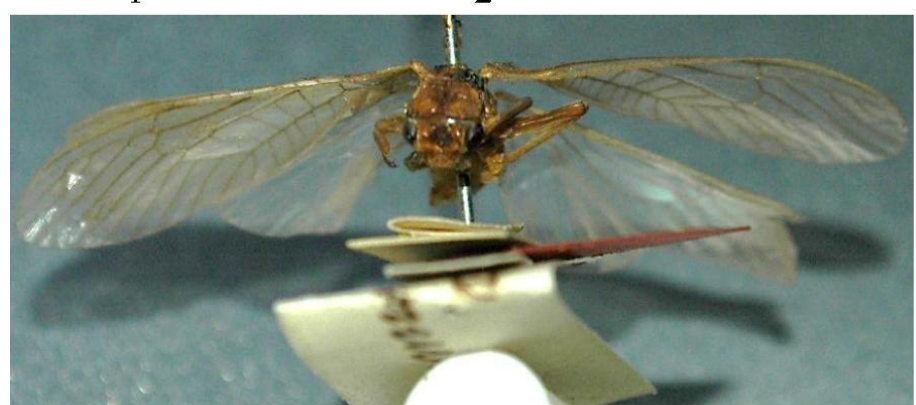

4

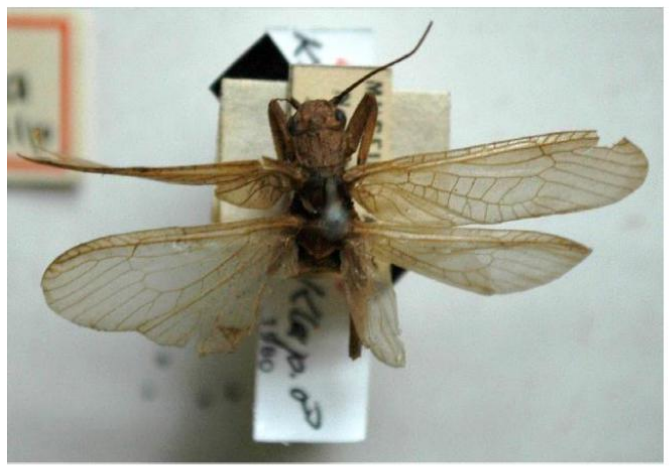

6

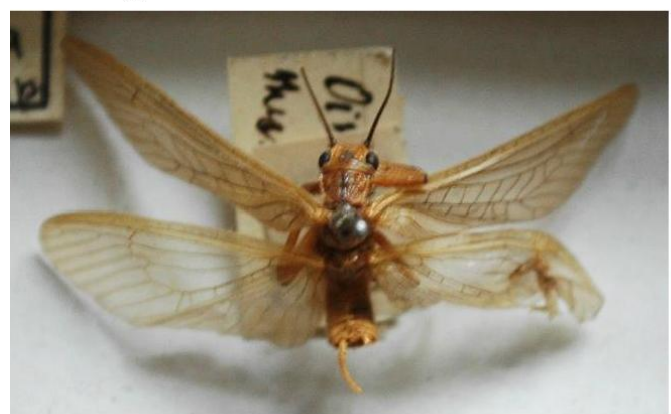

8

2

7

9
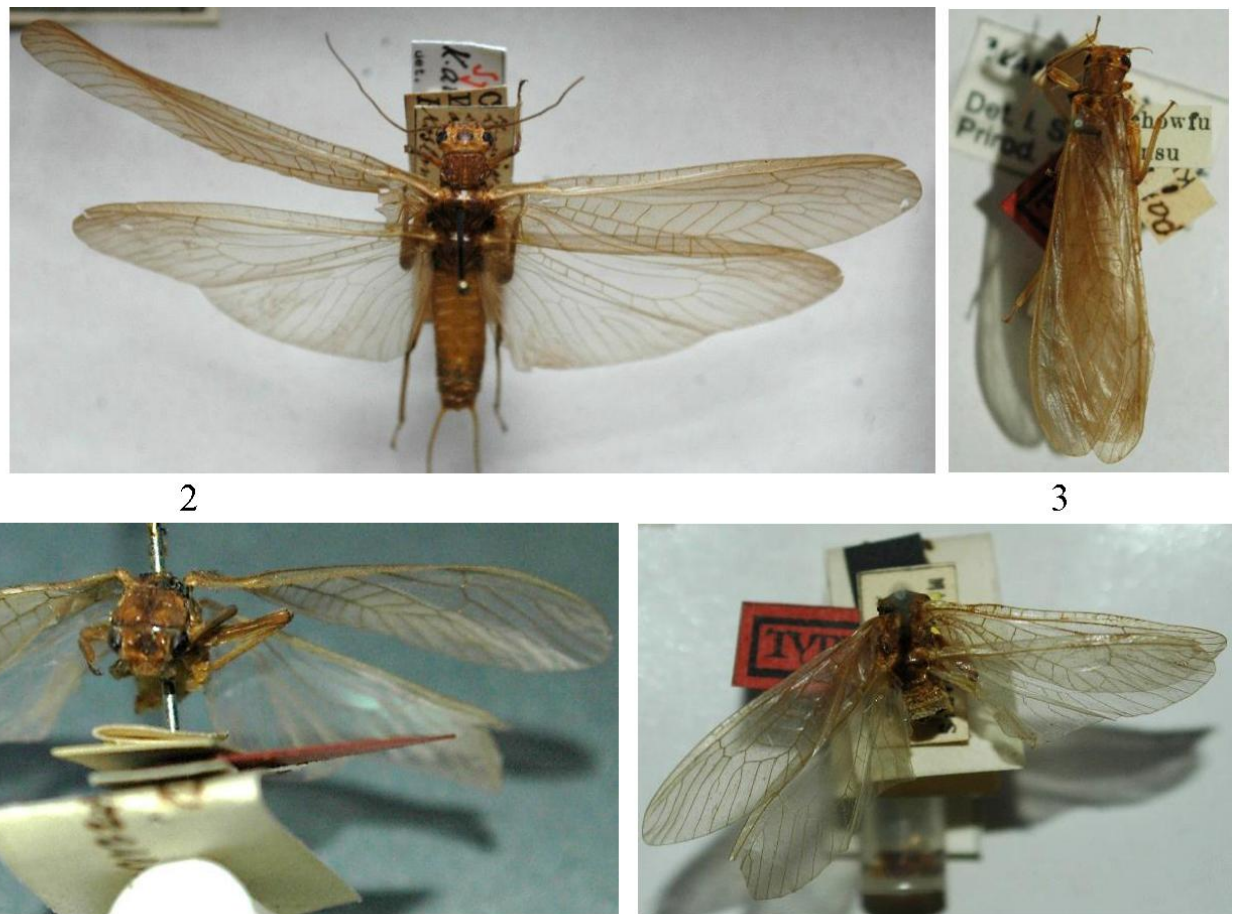

5
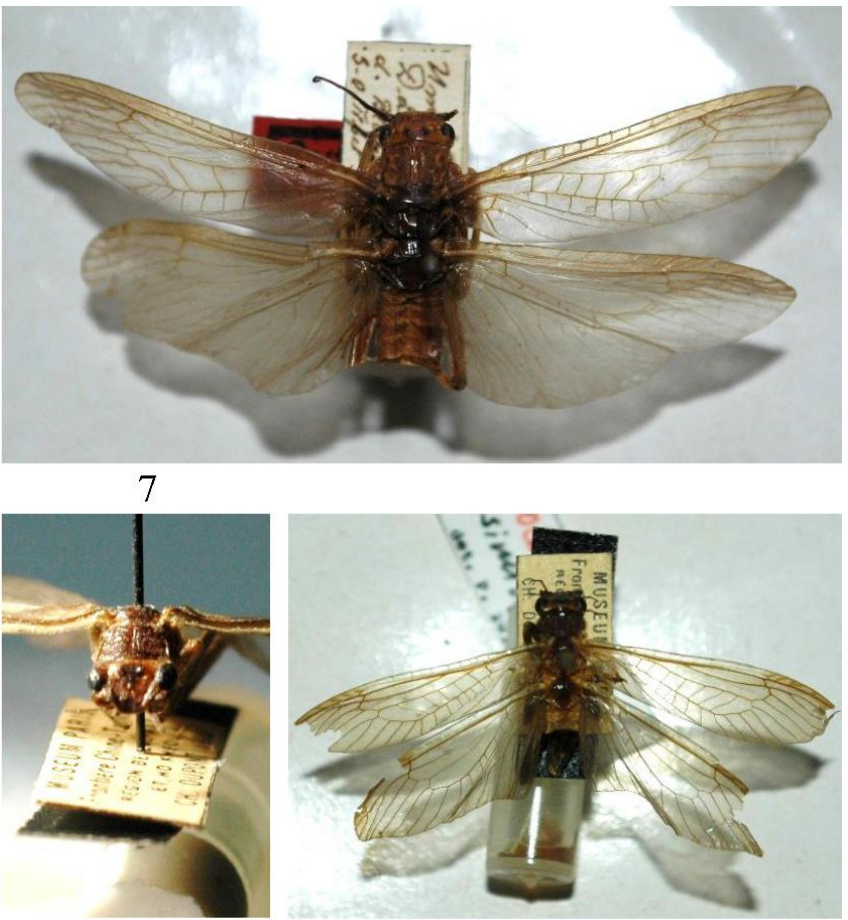

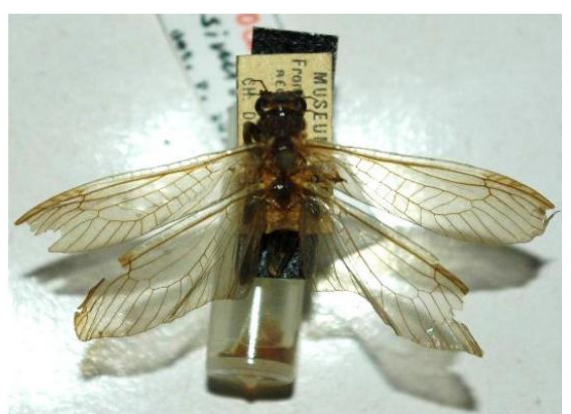

10

Appendix figures 1-10. Habitus photos of Klapálek's Kamimuria types kept in the NMP. 1-2 = female syntypes of Kamimuria amoena Klapálek, 1912a; 3 = female holotype of Paragnetina integra Klapálek, 1916; 4-5 = female holotype of Marthamea brunneicornis Klapálek, 1921; 6 = male syntype of Kamimuria coarctata Klapálek, 1912a; 7 = female syntype of Kamimuria latior Klapálek, 1912a; 8 = male syntype of Perla (Kamimuria) quadrata Klapálek, 1907b; 9-10 = male holotype of Kamimuria similis Klapálek, 1912a. Not to scale. 